\title{
Information systems, agency problems, and fraud
}

\section{Special section, information systems frontiers}

\author{
Douglas Cumming $^{1} \cdot$ Sofia Johan ${ }^{1,2} \cdot$ Denis Schweizer $^{3}$
}

Published online: 25 April 2017

(C) Springer Science+Business Media New York 2017

\section{Editorial}

The Internet has revolutionized the rapidity and the efficiency of information flows through the news media and social networks. Intermediaries have developed myriad uses for the Internet, from enabling internationalization through marketing channels, to increasing the speed of communications and transactions. It has also decreased the human and financial resource limitations for entrepreneurs. New forms of Internet-based financing, such as crowdfunding or peer-topeer lending, for example, have become increasingly widespread.

In terms of corporate governance, the Internet has had a profound effect in several significant ways, such as, e.g., shifts in firm governance from boards of directors to shareholders or backers. This shift to the Internet, in turn, has influenced networks, marketing services, human resource decisions, the offshore outsourcing of labor, and financing. The global reach of the Internet also impacts critical factors such as tax systems,

Denis Schweizer

denis.schweizer@ concordia.ca; http://ssrn.com/author=744422

Douglas Cumming

dcumming@schulich.yorku.ca; http://ssrn.com/author=75390

Sofia Johan

sjohan@schulich.yorku.ca; http://ssrn.com/author=370203

1 Schulich School of Business, York University, 4700 Keele Street, Toronto, ON M3J 1P3, Canada

2 Extramural Research Fellow, Tilburg Law and Economics Centre (TILEC), University of Tilburg, Postbus 90153, 5000, LE Tilburg, The Netherlands

3 John Molson School of Business, Concordia University, 1450 Guy Street, Montreal, Quebec H3H 0A1, Canada the regulatory environment, legislation, national technological infrastructures, and payment methods.

On a related note, the Internet offers new innovative forms of knowledge transfer, such as Massive Open Online Courses (MOOC) and more cost-effective distance learning technologies. These methods can increase community interaction and simplify fundraising. However, one down side to the Internet is that it can offer new mechanisms to carry out fraud (Cumming et al. 2016). Despite widespread media attention, the relation between information technology and fraud is under researched in academic journals worldwide (see also Weerakkody et al. 2015, for a similar conclusion reviewing related literature specific to government). The evolving structure of financial markets, in conjunction with the Internet, has recently given rise to an avalanche of new work on these topics.

The topics of fraud and information technology, for example, in the context of new forms of entrepreneurial financing like crowdfunding, have been of significant interest in recent literature. Evidence on the evolution and the importance of these topics is illustrated in Fig. 1. By itself, while the Internet as a topic of research has seen its popularity wane in recent years, there has been growth in new research that is clearly focused more on the intersection of the Internet with fraud and information technology (see, e.g., Cumming et al. 2016).

On June 2-3, 2016, Concordia University hosted a special issue conference that featured a timely debate on Information Systems, Agency Problems, and Fraud. Leading researchers from around the world debated topics that included: 1) the role of information technology in mitigating information asymmetries and hence agency problems and fraud, 2) the role of the Internet in facilitating financial transactions and mitigating default and fraud though crowdfunding portals, 3) the financial market consequences of misconduct and fraud, and 


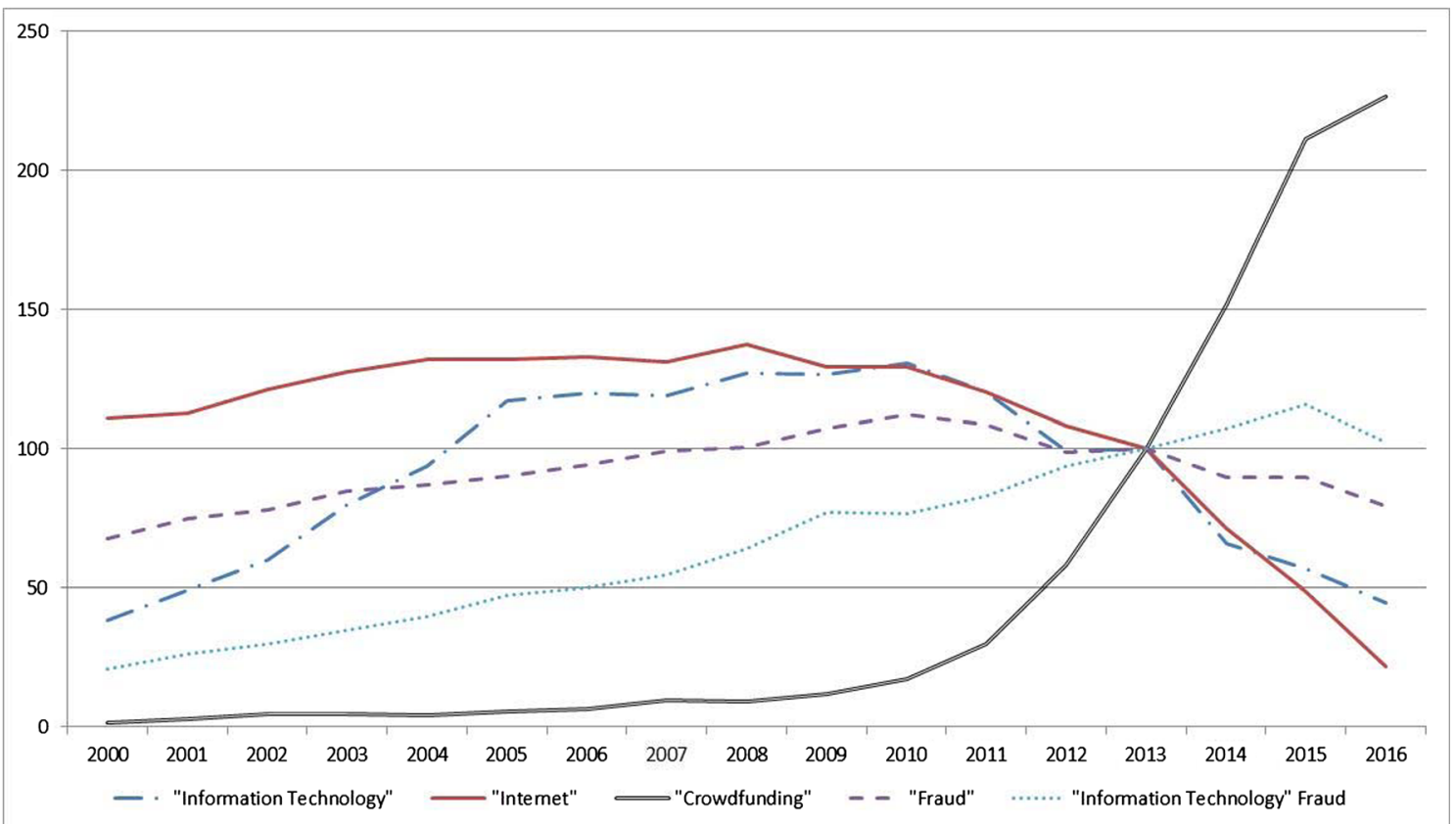

Fig. 1 Google Scholar Hits on Various Search Terms for Information Systems, Agency Problems, and Fraud

4) the governance consequences for firms and management. Specifically, attendees explored whether these consequences are distinct to the information technology sector, and they also focused on how the regulatory regime responds under different institutional environments.

The best papers at the conference were selected for this special section of Information Systems Frontier, and are summarized in Table 1. The papers cover topics ranging from peer-to-peer crowdfunding and loan default, to the prosecution of computer-assisted fraud, to stock price reactions to the commission of fraud.

Tao et al. (2017) study peer-to-peer lending in China, which is one of the fastest growing crowdfunding marketplaces in the world. They find significant evidence that the personal characteristics of borrowers matter when obtaining a loan. The interest rate and the likelihood of default were also important.

The credit ratings assigned to borrowers, in contrast, do not explain the likelihood of default efficiently. The evidence is particularly interesting in this context because it has significant policy implications for the development and regulation of online peer-to-peer lending on crowdfunding markets, as well as the supervisory role of platforms and ratings agencies.

Furthermore, note that several recent studies have studied companies (as opposed to individuals) borrowing from individuals in other contexts. In Germany, e.g., researchers have found differential evidence that credit ratings provided by lenders are more important than firms' financial conditions in determining the likelihood of a borrower obtaining funds and the interest rate (Cumming and Hornuf 2016). Further research may want to more closely examine the differences between individuals versus companies that lend to individuals, and examine the differences across countries and across crowdfunding platforms.

Liao et al. (2017) explore the role of the offender and the offense characteristics in computer-assisted fraud in the U.S. They find that the prosecution and conviction of offenders tend to differ among commonly seen types of frauds, and are dependent on the type of offense. For example, personalized fraud (fake documents and/or fake identities) is less likely to lead to arrest than impersonal fraud (credit card/payment fraud).

Their results provide some key insights to policymakers to assist in the systematic detection and prosecution of computerassisted fraud, as well as to firms that seek to mitigate fraud in their organizations. Liao et al.'s (2017) evidence also adds to a growing body of important work on the role of competencies and internal audit activity in organizations (Foorthuis et al. 2016; Goldschmidt 2007; Huang et al. 2016; Wu et al. 2016).

Switzer and Wang (2017) and Pukthuanthong et al. (2017) study the share price reaction to fraud in Canada and the U.S., with a focus on how the IT industry and corporate governance mechanisms can mitigate the wealth effects of fraud. They find that fraud has a massive impact on shareholder wealth, but that improved information and corporate governance, as well as more timely governance (such as timelier CEO turnover; Aharony et al. 2015), can mitigate the negative wealth effects. The evidence is consistent with related work 


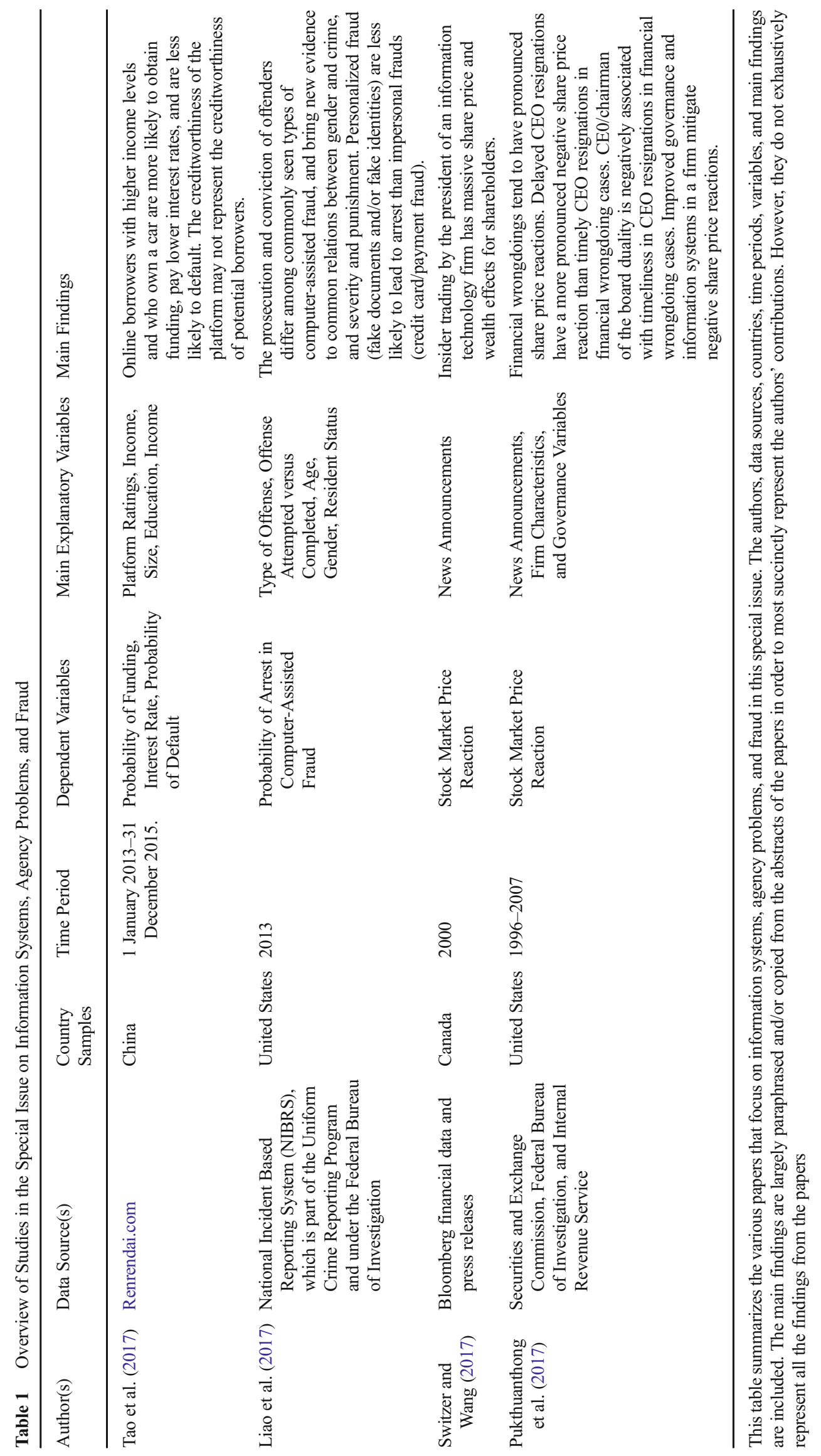


that shows the importance of governance in other industries and other countries at a firm level (Agrawal and Cooper 2015; Atanasov et al. 2015; Bernile et al. 2015; $\mathrm{Ha}$ et al. 2015; Karpoff et al. 2008a, 2008b; Zhou and Reesor 2015), an intermediary level (Chircop et al. 2017; Cumming et al. 2013; Vismara et al. 2015), and a country level with respect to securities industry computer surveillance (Cumming and Johan 2008), and enforcement (Aitken et al. 2015; Cumming et al. 2011, 2017; see also Cumming et al. 2015, for an overview of the related literature).

Overall, the evidence in this special section on Information Systems Frontiers points to the growing importance of the intersection between information systems and fraud. Information systems have great potential to improve surveillance and corporate governance, as well as mitigate the frequency and severity of fraud. New developments on, e.g., the crowdfunding marketplace, offer new research contexts from which to study fraud. But they also offer new insights into how information systems can enable governance improvements that inform the best practices among industry players and regulators in various institutional contexts around the world. It is our hope that the papers in this special section will inspire a wealth of related research on the topic in the coming years.

Acknowledgements The authors thank an anonymous referee and the seminar participants at the 2016 Concordia-Schulich Conference on Information Systems, Agency Problems, and Fraud for helpful comments and suggestions. They also thank Concordia University, the Schulich School of Business, and the Social Sciences and Humanities Research Council of Canada for financial support.

\section{References}

Agrawal, A., \& Cooper, T. (2015). Insider trading before accounting scandals. Journal of Corporate Finance, 34, 169-190.

Aharony, J., Liu, C., \& Yawson, A. (2015). Corporate litigation and executive turnover. Journal of Corporate Finance, 34, 268-292.

Aitken, M., Cumming, D. J., \& Zhan, F. (2015). Exchange trading Rules, surveillance, and suspected Insider trading. Journal of Corporate Finance, 34, 311-330.

Atanasov, V., Davies, R. J., \& Merrick, J. J. (2015). Financial intermediaries in the midst of market manipulation: Did they protect the fool or help the knave? Journal of Corporate Finance, 34, 210-234.

Bernile, G., Sulaeman, J., \& Wang, Q. (2015). Institutional trading during a wave of corporate scandals: 'perfect payday'? Journal of Corporate Finance, 34, 191-209.

Chircop, J., Johan, S. A., Tarsalewska, M. (2017). Common auditors and Cross-Country M\&a Transactions. Journal of International Financial Markets, Institutions and Money. Forthcoming.

Cumming, D. J., \& Hornuf, L. (2016). Marketplace Lending of SMEs. Available at SSRN: https://ssrn.com/abstract $=2894574$.

Cumming, D. J., \& Johan, S. A. (2008). Global market surveillance. American Law and Economics Review, 10, 454-506.
Cumming, D. J., Johan, S. A., \& Li, D. (2011). Exchange trading Rules and stock market liquidity. Journal of Financial Economics, 99, 651-671.

Cumming, D. J., Dai, N., Johan, S. A. (2013). Hedge fund structure, regulation and performance around the World. Oxford University Press.

Cumming, D. J., Dannhauser, B., \& Johan, S. A. (2015). Financial market misconduct and agency conflicts: A synthesis and future directions. Journal of Corporate Finance, 34, 150-168.

Cumming, D. J., Hornuf, L., Karami, M., Schweizer, D. (2016). Disentangling Crowdfunding from Fraudfunding. Max Planck Institute for Innovation \& competition research paper no. 16-09. Available at SSRN: https://ssrn.com/abstract=2828919.

Cumming, D. J., Groh, A., and Johan, S.A., (2017). Same Rules, Different Enforcement: Market Abuse in Europe. Journal of International Financial Markets, Institutions, \& Money, forthcoming.

Foorthuis, R., van Steenbergen, M., Brinkkemper, S., \& Bruls, W. (2016). A theory building study of Enterprise architecture practices and benefits. Information Systems Frontiers, 18, 541-564.

Goldschmidt, P. (2007). Managing the false alarms: A framework for assurance and verification of surveillance monitoring. Information Systems Frontiers, 9, 541-556.

Haß, L. H., Müller, M. A., \& Vergauwe, S. (2015). Tournament incentives and corporate fraud. Journal of Corporate Finance, 34, 251-267.

Huang, S. Y., Lin, C.-C., Chiu, A.-A., \& Yen, D. C. (2016). Fraud detection using fraud triangle risk factors. Information Systems Frontiers, $18,1-14$

Karpoff, J., Lee, D. S., \& Martin, G. S. (2008a). The consequences to managers for cooking the books. Journal of Financial Economics, $88,193-215$.

Karpoff, J. M., Lee, D. S., \& Martin, G. S. (2008b). The consequences to managers for financial misrepresentation. Journal of Financial Economics, 85, 66-101.

Liao, R., Balasinorwala, S., and Rao, H.R. (2017) Computer assisted Frauds: An Examination of Offender and Offense Characteristics in Relation to Arrests. Information Systems Frontiers. doi:10.1007/ s10796-017-9752-4.

Pukthuanthong, K., Ullah, S., Walker, T. J., \& Wu, X. (2017). Timely vs. Delayed CEO Turnover. Information Systems Frontiers. doi:10. 1007/s10796-017-9754-2.

Switzer, L. N., \& Wang, J. (2017). An event based approach for quantifying the effects of securities fraud in the IT industry. Information Systems Frontiers. doi:10.1007/s10796-017-9753-3.

Tao, Q., Dong, Y., \& Lin, Z. (2017). Who can get Money? Evidence from the Chinese Peer-to-Peer Lending Platform. Information Systems Frontiers. doi:10.1007/s10796-017-9751-5.

Vismara, S., Signori, A., \& Palearia, S. (2015). Changes in Underwriters' selection of comparable firms pre- and post-IPO: Same Bank, Same company, different peers. Journal of Corporate Finance, 34, 235-250.

Weerakkody, V., Irani, Z., Lee, H., \& Osman, I. (2015). E-government implementation: A Bird's eye view of issues relating to costs, opportunities, benefits and risks. Information Systems Frontiers, 17, 889-915.

Wu, T. H., Huang, S. M., \& Huang, S. Y. (2016). The effect of competencies, team problem-solving ability, and computer audit activity on internal audit performance. Information Systems Frontiers, 1-16. doi:10.1007/s10796-015-9620-z

Zhou, X., \& Reesor, R. M. (2015). Misrepresentation and capital structure: Quantifying the impact on corporate security value in a modified Merton framework. Journal of Corporate Finance, 34, 293-310. 